Original Research Paper

\title{
Antimicrobial Activities of Unconventional Compounds against Some Bacteria Associated with Skin Infections in Humans, Sheep and Goats
}

\author{
${ }^{1,2}$ Iman Shabana and ${ }^{1,3}$ Amira El-Adly \\ ${ }^{1}$ Department of Biology, Faculty of Science, Taibah University, Al Madinah Al Munawarah, Saudi Arabia \\ ${ }^{2}$ Department of Bacteriology, Immunology and Mycology, Faculty of Veterinary medicine, Suez Canal University, Egypt \\ ${ }^{3}$ Laser Microbiology Laboratory, National Institute of Laser Enhanced Science, Cairo University, Egypt
}

Article history

Received: 28-11-2015

Revised: 05-01-2016

Accepted: 06-01-20116

Corresponding Author: Iman Shabana,

Department of Bacteriology, Immunology and Mycology, Faculty of Veterinary medicine, Suez Canal University, Egypt Email: imanibrahim50@yahoo.com

\section{Introduction}

Bacterial skin infections are very common and they can range from merely annoying to deadly. Most bacterial infections of the skin are caused by grampositive bacteria (Streptococcus, Staphylococcus) and gram-negative (e.g., Klebsiella, Escherichia coli, Pseudomonas) (AFHSC, 2013). Pyogenic skin infections of sheep and goats are of worldwide distribution, especially in developing countries. It causes severe economic losses to sheep and goats producers due to decrease live animal sales, condemnation and downgrading of carcasses and skin in abattoirs as well as the reduction in wool growth (Koutinas et al., 2007). Bacterial skin infections are treated with antibiotics, but there is a concern that widespread antibiotic use might lead to antibiotic resistance. Antibiotics resistance are an

\begin{abstract}
Bacterial skin infections are a common problem encountered in clinical practice and causing great economic losses for sheep and goats producers. Increasing multidrug resistance of pathogens paves the way for reconsidering alternative medicine. The present study was carried out to explore the antibacterial activities of different volumes; 5, 25, 50 and 100 $\mu \mathrm{L}$ of gold nanoparticles (NPS) and the aqueous and ethanolic extracts of $100 \%$, turmeric and cinnamon at different concentrations (20, 40, 80 and Streptococcus pyogenes, Pseudomonas aeruginosa and Escherichia coli isolated from skin pyogenic lesions in humans, sheep and goats using disc diffusion assay. The results compared with ciprofloxacin $\left(5 \mu \mathrm{g} \mathrm{mL}^{-1}\right)$. Gold nanoparticles (NPS) $100 \mu \mathrm{L}$ were highly effective against Pseudomonas aeruginosa and Escherichia coli in comparing with ciprofloxacin $\left(5 \mu \mathrm{g} \mathrm{mL}^{-1}\right)$. Garlic has shown better activity against Staphylococcus aureus and Streptococcus pyogenes in aqueous solution while the ethanolic extract of cing and turmeric was more efficient than the aqueous extract. Among the three tested spices, turmeric was the least effective against tested bacteria. The proven activity of $100 \mu \mathrm{L}$ Gold nanoparticles (NPS) and $100 \%$ aqueous garlic extract compared with ciprofloxacin $\left(5 \mu \mathrm{g} \mathrm{mL} \mathrm{L}^{-1}\right)$, suggests their use in clinical trials as an alternative medicine to reduce the
\end{abstract}

Keywords: S. aureus, S. pyogenes, Ps. aeruginosa, E. coli, GNPS, Spices

increasing public health problem. Multiple drug resistance has been developed due to the indiscriminate use of commercial antimicrobial drugs commonly used in the treatment of infectious diseases. In addition, antibiotics are sometimes associated with adverse effects on the host including hypersensitivity, immunesuppression, allergic reactions. Certain strains of bacteria are able to produce substances which block the action of antibiotics or change their target or ability to penetrate cells (Aly, 2013). This situation forced scientists to search for a new treatment that does not generate resistance and present a good bactericidal property. Gold-nanoparticles have a great bactericidal effect on a wide range of bacteria; its bactericidal effect depends on the size and the shape of the particle (Nirmala et al., 2011). Nanoparticles can act as antibacterial and antifungal agents, due to their ability to interact with 
microorganisms (Eby et al., 2009; Panacek et al., 2009). Nanoparticles attach to the surface of the cell, this interaction causes structural changes and damage; markedly disturbing vital cell functions such as permeability, causing pits and gaps, depressing the activity of respiratory chain enzymes and finally leading to cell death (Li et al., 2010). Several species of plants have been used for centuries as remedies for human diseases because they contain components of therapeutic values (Kaushik et al., 2011). Recently, the acceptance of traditional medicine as an alternative form of health care and the development of microbial resistance to the available antibiotics, have led researchers to investigate the antimicrobial activity of medicinal plants (Samie et al., 2009). Medicinal plants produce certain bioactive molecules which show both antibacterial and antifungal activities (Violante et al., 2012). Many medicinal plants produce antioxidant and antimicrobial properties which protect the host from cellular oxidation reactions and other pathogens highlighting the importance of looking for natural antimicrobial drugs (Farzaei et al., 2014; Bajpai et al., 2005). Garlic has generated a lot of interest as a medicinal plant. A broad range of microorganism including bacteria, fungi, protozoa and viruses has been found to be responsive to crushed garlic preparations. Chemical analysis of garlic has revealed an unusual concentration of sulfur-containing compounds which have antibiosis effect (Shaheen et al., 2015). Cinnamon has a potential medical use with regards to its antimicrobial properties, especially antibacterial activity (Nabavi et al., 2015). Turmeric is known to possess multifunctional properties, including antibacterial activity (Izui et al., 2015).

The aim of the present study was to identify different etiological pathogens which inhabit the pyogenic skin lesions in humans, sheep and goats and find the inhibitory activity of gold nanoparticles and different concentrations of the aqueous and ethanolic extracts of garlic, cinnamon, turmeric against Staphylococcus aureus, Streptococcus pyogenes, Pseudomonas aeruginosa and Escherichia coli isolates, associated with pyogenic skin infections in comparing with ciprofloxacin $\left(5 \mu \mathrm{g} \mathrm{mL}^{-1}\right)$.

\section{Materials and Methods}

\section{Bacterial Isolates}

Swabs from pyogenic skin lesions were collected from patients in King Fahd hospital at Al-Madinah AlMunawarah, sterile cotton swabs which were moistened with sterile saline to prevent drying were used for sample collection. A swab from the affected area or the exudates of the lesions were collected from the affected sheep and goats. The specimens were brought to the laboratory in a sterile container within one hour after the collection and processed immediately and inoculated on MaCconkey agar and blood agar plates for isolating the pathogens. The inoculated plates were incubated at $37^{\circ} \mathrm{C}$ overnight. After incubation, the plates were observed for growth and the isolated colonies were identified by morphological and biochemical characteristics. The tests performed include Gram staining, Motility, Catalase, Oxidase, Indole, Methyl Red, Voges-Proskauer, Citrate Utilization production, Urease production, Triple Sugar Iron, Mannitol, Phenylalanine (Koneman et al., 2005). The pure cultures were refreshed on Nutrient agar slant and kept in the incubator for $24 \mathrm{~h}$ at $37^{\circ} \mathrm{C}$ then stored at $4^{\circ} \mathrm{C}$.

\section{Molecular Identification of Isolates}

\section{Template DNA Preparation}

DNA templates for PCR were obtained from overnight bacterial cultures that were suspended in $200 \mathrm{~mL}$ of sterile distilled water and boiled for $15 \mathrm{~min}$ (Usein et al., 2009).

\section{Polymerase Chain Reaction (PCR)}

Detection of a species-specific gene (uidA) in E. coli, (ecfX) in Pseudomonas areuginosa and 16s rRNA in staphylococcus aureus and streptococcus pyogens were performed by conventional PCR (Moyo et al., 2007; AlTalib et al., 2009; Clifford et al., 2012). Primer sequences and PCR conditions used for the study are listed in Table 1. PCR was performed in the Takara thermal cycler (Bio-Rad). PCR products were separated and visualized by gel electrophoresis in 1.5\% agarose (Wako, Japan) in Tris-Acetate-Edta (TAE) buffer at 100 V. A 100 or 500 bp DNA ladder (one-step ladder, Wako) was included in each agarose run, according to the amplified product.

\section{Gold Nanoparticles Preparation}

Gold colloids 5, 25, 50 and $100 \mu \mathrm{L}$ were prepared by citrate thermal reduction method (Yang et al., 2005). In this method, a gold solution was prepared by adding $1 \mathrm{~mL}$ of $1 \%$ hydrogen tetra-chloroauric (HAucl4.3H2O) aqueous solution and $1.5 \mathrm{~mL}$ of 38.8 $\mathrm{mM}$ sodium citrate aqueous solution into $90 \mathrm{~mL}$ boiling water. After the solution had turned purple-red within the $30 \mathrm{~s}$, the solution was cooled quickly in an ice bath. This indicated the dispersion of gold particles with an average diameter of around $12 \mathrm{~mm}$ width and $40 \mathrm{~mm}$ length. $0.2 \mathrm{~mL}$ of $0.1 \mathrm{M}$ freshly prepared acetyl Trimethyl Ammonium Bromide (CTAB) aqueous solution was added to $20 \mathrm{~mL}$ of prepared gold colloid at room temperature. Finally, 1 $\mathrm{mL}$ of $0.5 \mathrm{mM}$ of 11-Mercaptoundecanoic (MUA) aqueous solution was added to the gold colloidmodified by $0.1 \mathrm{mM}$ of CTAB in order to restrain the over much aggregation process. 
Table 1. PCR primers and conditions for amplification of virulence genes

\begin{tabular}{|c|c|c|c|c|c|}
\hline Target gene & $\begin{array}{l}\text { Primer } \\
\text { designation }\end{array}$ & Primer sequence $\left(5^{\prime}-3^{\prime}\right)$ & $\begin{array}{l}\text { Length }(b p) \\
\text { PCR conditions * }\end{array}$ & PCR product & Reference \\
\hline$\overline{U i d A}$ (E. coli) & $\begin{array}{l}\text { UidA-F } \\
\text { UidA-R }\end{array}$ & $\begin{array}{l}\text { CCAAAAGCCAGACAGAGT } \\
\text { GCACAGCACATCAAAGAG }\end{array}$ & $95^{\circ} \mathrm{C}, 30 \mathrm{~s} ; 57^{\circ} \mathrm{C}, 30 \mathrm{~s} ; 72^{\circ} \mathrm{C}, 30 \mathrm{~s}$ & 623 & 42 \\
\hline $\begin{array}{l}\text { 16S rRNA } \\
\text { (S. aureus) }\end{array}$ & $\begin{array}{l}16 S \text { rRNA-F } \\
16 S \text { rRNA-R }\end{array}$ & $\begin{array}{l}\text { GCAAGCGTTATCCGGATTT } \\
\text { CTTAATGATGGCAACTAAG }\end{array}$ & $95^{\circ} \mathrm{C}, 30 \mathrm{~s} ; 57^{\circ} \mathrm{C}, 30 \mathrm{~s} ; 72^{\circ} \mathrm{C}, 30 \mathrm{~s}$ & 597 & 43 \\
\hline $\begin{array}{l}\text { ecfX } \\
\text { (Ps. aeruginosa) }\end{array}$ & $\begin{array}{l}\text { ecfXRT-F } \\
\text { ecfXRT-R }\end{array}$ & $\begin{array}{l}\text { AGCGTTCGTCCTGCACAAGT } \\
\text { TCCACCATGCTCAGGGAGAT }\end{array}$ & $95^{\circ} \mathrm{C}, 30 \mathrm{~s} ; 52^{\circ} \mathrm{C}, 30 \mathrm{~s} ; 72^{\circ} \mathrm{C}, 30 \mathrm{~s}$ & 81 & 44 \\
\hline $\begin{array}{l}\text { 16S rRNA } \\
\text { (S. pyogenes) }\end{array}$ & $\begin{array}{l}16 S r R N A-F \\
16 S r R N A-R\end{array}$ & $\begin{array}{l}\text { CAGTTCGGATTGTAGGCTGC } \\
\text { ACCCCAATCATCTATCCCACC }\end{array}$ & $95^{\circ} \mathrm{C}, 30 \mathrm{~s} ; 52^{\circ} \mathrm{C}, 30 \mathrm{~s} ; 72^{\circ} \mathrm{C}, 30 \mathrm{~s}$ & 194 & $\begin{array}{l}\text { The current } \\
\text { study }\end{array}$ \\
\hline
\end{tabular}

\section{Extract and Preparation of Plant Materials}

The spices including Garlic (Allium sativum), Turmeric (Curcuma longa) and Cinnamon (Cinnamomum zeylanicum) were purchased from local market. The species were washed with distilled water thoroughly. Garlic (100 mg each) were washed by distilled water, homogenized using sterile mortar or blender and then saved through double layer of sterile line mesh cloth to make $100 \%$ extract. Turmeric, Cinnamon (100 mg each) was crushed and sieved through mesh cloth to get the fine powder. Powdered spices were soaked in $200 \mathrm{~mL}$ of sterile distilled water and kept at room temperature for $24 \mathrm{~h}$, then were filtered using Whatman filter paper. The filtrate was kept at room temperature until dry and thick layer formed. The drying thick layer was considered as $100 \%$ extract. This extract was stored at $4^{\circ} \mathrm{C}$, further diluted to make different concentrations such as 80,40 and $20 \%$ by mixing with appropriate volumes of distilled water. The ethanolic extract was prepared following the same procedure with the exception of solvent which was $95 \%$ ethanolic instead of sterilized distilled water.

\section{Antimicrobial Activity Testing}

Standard well agar diffusion method was carried out to detect the activity of gold nanoparticles and garlic, cinnamon, turmeric in aqueous and ethanolic extract against pathogenic bacterial isolates according to (Cheesbrough, 2000). Only $100 \mathrm{~mL}$ of the overnight 0.5 McFarland suspension of each isolate were inoculated into $100 \mathrm{~mL}$ warm nutrient agar medium $\left(45-55^{\circ} \mathrm{C}\right)$. The media were poured in sterile plates and left for solidification. Each plate is called a seeded plate. The seeded plates with the isolated bacteria were cut by sterile cork borer to make holes $(8 \mathrm{~mm}$ in diameter). Each hole was saturated $(100 \mathrm{~mL})$ with different volumes of gold nanoparticles $(5,25,50$ and $100 \mu \mathrm{L}), 100 \mathrm{~mL}$ of the ethanol extract and aqueous extract of garlic, cinnamon and turmeric were transferred into each hole at all dilutions and $50 \mu \mathrm{L}$ ciprofloxacin $(5 \mu \mathrm{L})$ under aseptic conditions. Then, the plates were kept in the refrigerator for $2 \mathrm{~h}$ before incubation to permit diffusion of the extract before the growth of the tested isolates takes place. The plates were incubated at $37^{\circ} \mathrm{C}$ for $24 \mathrm{~h}$ and then examined for antibacterial activity. Duplicate plates were used for each isolate. The detection of clear inhibition zones around the wells on the inoculated plates is an indication of antimicrobial activity.

\section{Antimicrobial Activity of Ciprofloxacin $\left(5 \mu \mathrm{g} \mathrm{mL}^{-1}\right)$}

Antimicrobial susceptibility testing of the isolates to ciprofloxacin $\left(5 \mu \mathrm{g} \mathrm{mL} \mathrm{m}^{-1}\right)$ was performed using the standard disc diffusion method; using commercially available antimicrobial susceptibility discs (Kirby-Bauer SN DISC, Nissui Pharmaceuticals, Tokyo, Japan) according to Clinical and Laboratory Standards Institute (CLSI) instructions (Wikler, 2006).

\section{Results}

\section{Bacterial Isolates}

Molecularly confirmed Staphylococcus aureus, Streptococcus pyogenes, Pseudomonas aeruginosa and Escherichia coli were obtained from pyogenic skin lesions.

\section{Characterization of Gold Nanoparticles}

Photo (1) shows TEM image of the obtained gold nanoparticles. The prepared gold nanoparticles were almost rod shape and separated from each other. The particle size mainly was $12 \mathrm{~nm}$ width and $40 \mathrm{~nm}$ length. The absorption spectrum of these gold rods has two characteristic absorption bands, one at 523 $\mathrm{nm}$ for transverse surface Plasmon resonance and the other at $753 \mathrm{~nm}$ for the longitudinal surface Plasmon band (Fig. 1).

\section{Antimicrobial Activity of Gold Nanoparticles}

Antibacterial activities of gold nanoparticles increased with higher volume; $100>50>25>5 \mu \mathrm{L}$. Gold nanoparticles (vol. $100 \mu \mathrm{L}$ ) showed great antimicrobial activities with the best inhibition zone against $P$ s. areuginosa $(27 \mathrm{~mm})$, E. coli $(25.5 \mathrm{~mm})$ and S. pyogens $(25 \mathrm{~mm})$ and $S$. aureus $(24 \mathrm{~mm})$ as shown in Fig. 2 and Table 2. The effect of ciprofloxacin antibiotics was also studied, the best results were against $S$. aureus with an inhibition zone of $(25 \mathrm{~mm})$. 


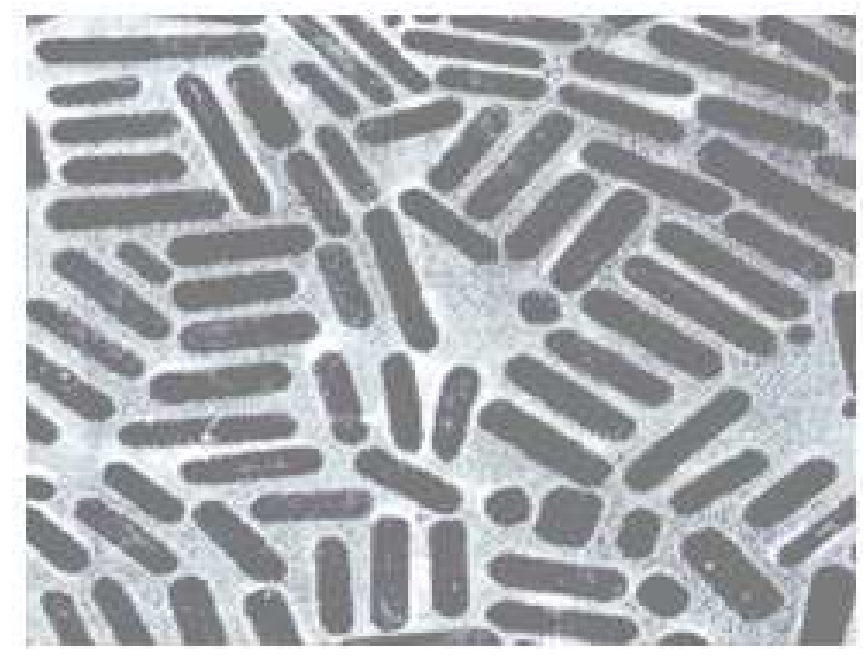

Fig. 1. TEM image of gold nanoparticles

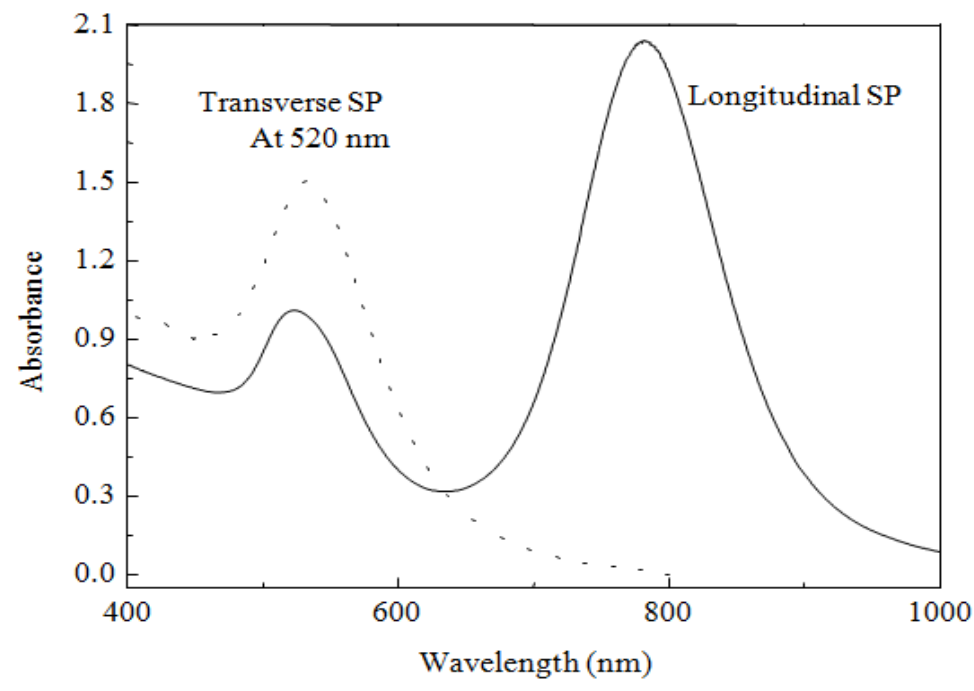

Fig. 2. Absorption spectra of gold nanoparticles

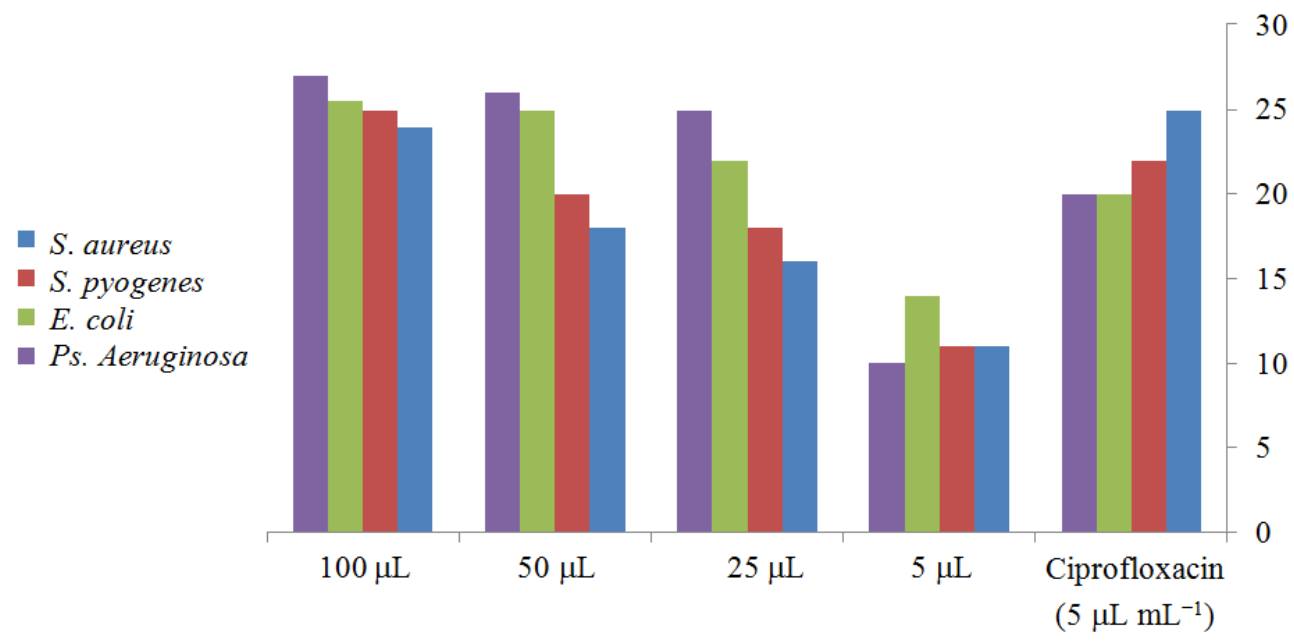

Fig. 3. Antibacterial activity of different volumes of gold nanoparticles against bacterial isolates compared with Ciprofloxacin $\left(5 \mu \mathrm{g} \mathrm{mL}{ }^{-1}\right)$ 


\section{Antimicrobial Activity of Garlic, Cinnamon and} Turmeric Solution

Among the three tested spices, garlic has shown the best activity at all concentrations both in aqueous and ethanolic solution. Garlic has shown better activity against $S$. aureus $(28 \mathrm{~mm})$ in aqueous solution as compared to the other tested bacteria. Aqueous extract of garlic was more effective as compared to ethanolic extract. The activity of $100 \%$ garlic extract was comparatively more than of ciprofloxacin $\left(5 \mu \mathrm{g} \mathrm{mL}^{-1}\right)$ (Fig. 3 and Table 3). The cinnamon ethanolic (100\%) extract was also effective against $E$. coli $(17 \mathrm{~mm})$. The ethanolic extract of cinnamon was more efficient in its antibacterial activity as compared to the aqueous extract (Fig. 4 and Table 4). Turmeric was less effective against tested bacteria among the three tested spices. The ethanol extract of turmeric showed better results as compared to the aqueous ones showing the largest inhibition zone against $S$. pyogens $(14.1 \mathrm{~mm})$ at $100 \%$ ethanolic extract (Fig. 5 and Table 5).

\section{Antimicrobial Activity of Ciprofloxacin $\left(5 \mu \mathrm{g} \mathrm{LL}^{-1}\right)$}

Ciprofloxacin showed high activity against the tested isolates, the largest inhibition zone $(25 \mathrm{~mm})$ was around $S$. aureus, followed by $S$. pyogenes, E. coli, PS. aeruginosa $(22,20$ and $20 \mathrm{~mm}$ respectively).

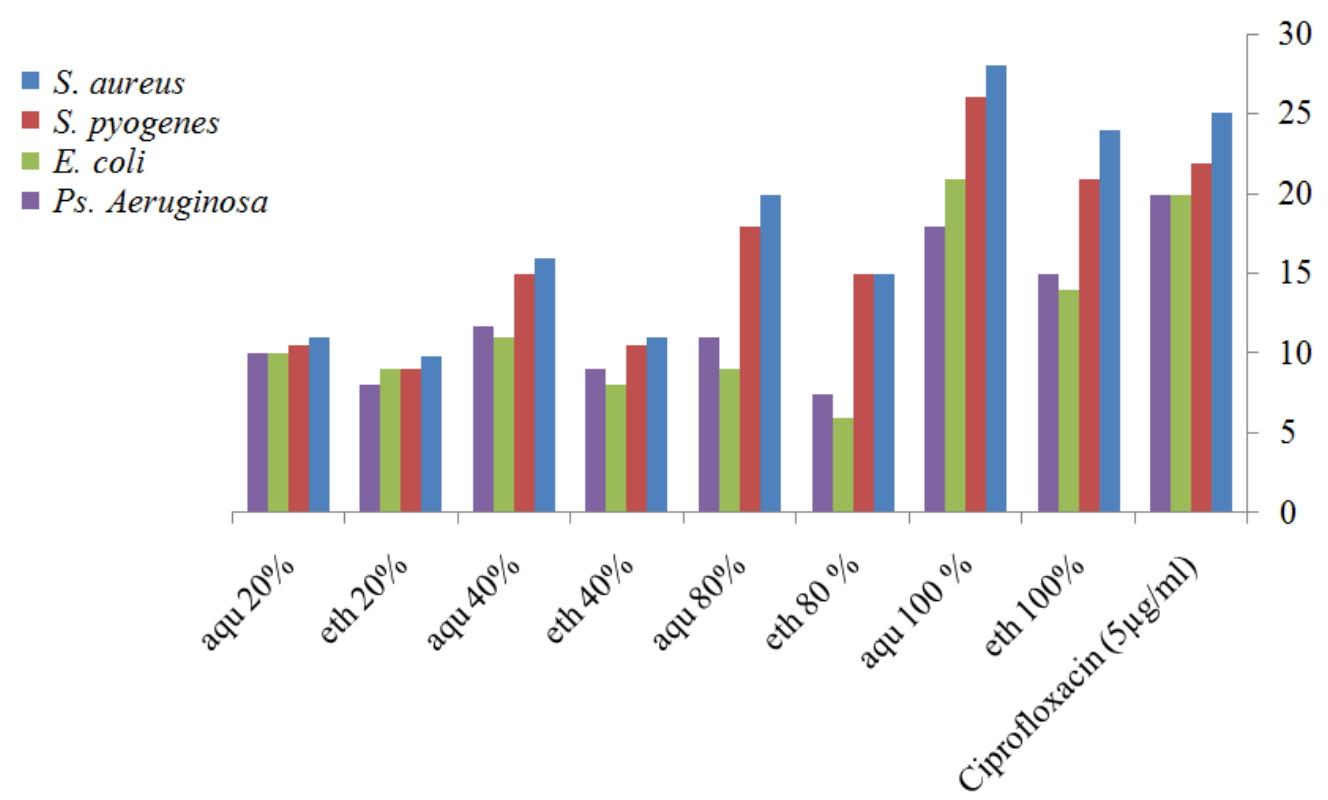

Fig. 4. Antibacterial activity of different concentrations of garlic against bacterial isolates compared with Ciprofloxacin $\left(5 \mu \mathrm{g} \mathrm{mL}^{-1}\right)$

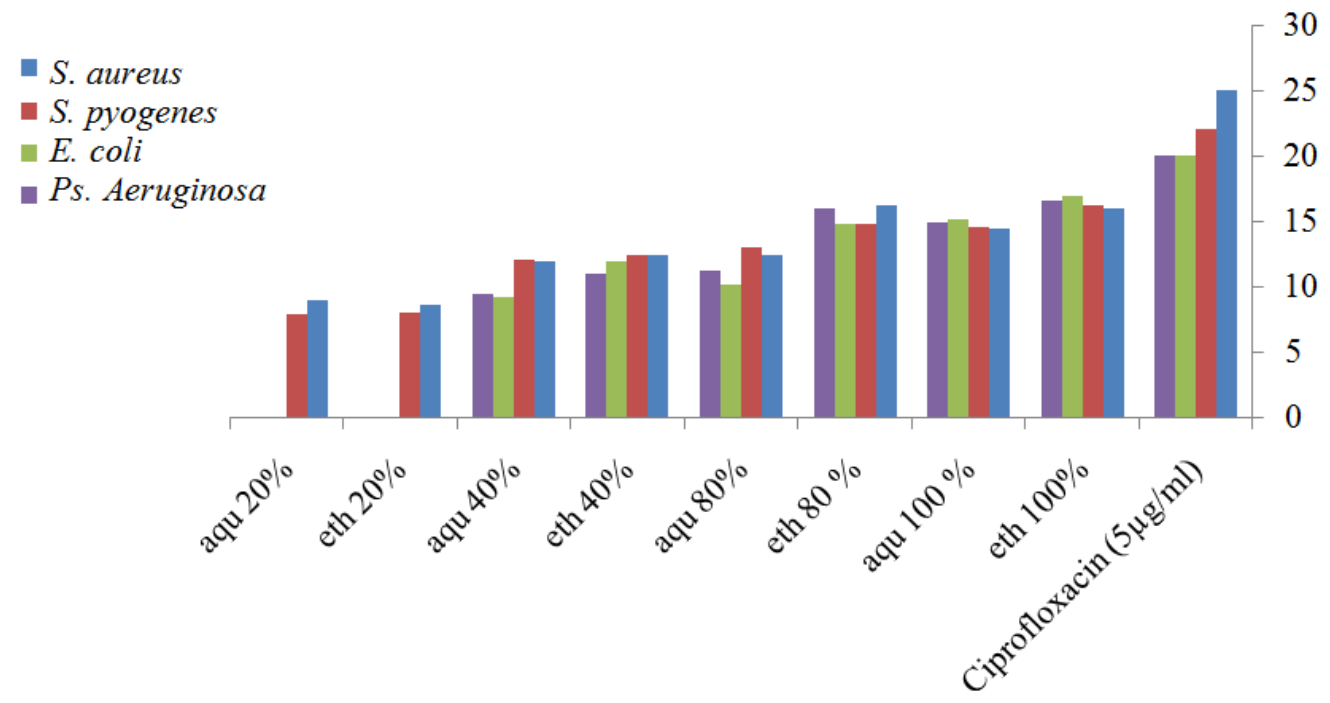

Fig. 5. Antibacterial activity of different concentrations of cinnamon against bacterial isolates compared with Ciprofloxacin $\left(5 \mu \mathrm{g} \mathrm{mL}^{-1}\right)$ 
Iman Shabana and Amira El-Adly / American Journal of Applied Sciences 2016, 13 (1): 36.45 DOI: 10.3844/ajassp.2016.36.45

Table 2. Antibacterial activity of different volumes of gold nanoparticles against bacterial isolates compared with Ciprofloxacin $\left(5 \mu \mathrm{g} \mathrm{mL}{ }^{-1}\right)$

\begin{tabular}{|c|c|c|c|c|c|}
\hline \multirow[b]{2}{*}{ Bacterial isolates } & \multicolumn{4}{|c|}{ Volume of gold nanoparticles $(\mu \mathrm{L})$} & \multirow{2}{*}{$\begin{array}{l}\text { Ciprofloxacin } \\
\left(5 \mu \mathrm{g} \mathrm{mL}^{-1}\right)\end{array}$} \\
\hline & $5 \mu \mathrm{L}$ & $25 \mu \mathrm{L}$ & $50 \mu \mathrm{L}$ & $100 \mu \mathrm{L}$ & \\
\hline S. aureus & $11 *$ & 16 & 18 & 24 & 25 \\
\hline S. pyogenes & 11 & 18 & 20 & 25 & 22 \\
\hline E. coli & 14 & 22 & 25 & 25.5 & 20 \\
\hline Ps. aeruginosa & 10 & 25 & 26 & 27 & 20 \\
\hline
\end{tabular}

* :Mean value of inhibition zone (mm)

Table 3. Antibacterial activity of different concentrations of garlic against bacterial isolates compared with Ciprofloxacin $\left(5 \mu \mathrm{g} \mathrm{mL} \mathrm{L}^{-1}\right)$

\begin{tabular}{|c|c|c|c|c|c|c|c|c|c|}
\hline \multirow{3}{*}{$\begin{array}{l}\text { Bacterial } \\
\text { isolates }\end{array}$} & \multicolumn{8}{|c|}{ Concentration } & \multirow{3}{*}{$\begin{array}{l}\text { Ciprofloxacin } \\
\left(5 \mu \mathrm{g} \mathrm{mL}^{-1}\right)\end{array}$} \\
\hline & \multicolumn{2}{|l|}{$20 \%$} & \multicolumn{2}{|l|}{$40 \%$} & \multicolumn{2}{|l|}{$80 \%$} & \multicolumn{2}{|l|}{$100 \%$} & \\
\hline & aqaous & ethanol & aqaous & ethanol & aqaous & ethanol & aqueous & ethanol & \\
\hline S. aureus & $11 *$ & 9.8 & 16.0 & 11.0 & 20 & 15.0 & 28 & 24 & 25 \\
\hline S. pyogenes & 10.5 & 9.0 & 15.0 & 10.5 & 18 & 15.0 & 26 & 21 & 22 \\
\hline E. coli & 10.0 & 9.0 & 11.0 & 8.0 & 9 & 6.0 & 21 & 41 & 20 \\
\hline Ps. aeruginosa & 10.0 & 8.0 & 11.7 & 9.0 & 11 & 7.5 & 18 & 15 & 20 \\
\hline
\end{tabular}

$*$ :Mean value of inhibition zone (mm)

Table 4. Antibacterial activity of different concentrations of cinnamon against bacterial isolates compared with Ciprofloxacin $\left(5 \mu \mathrm{g} \mathrm{mL}^{-1}\right)$

\begin{tabular}{|c|c|c|c|c|c|c|c|c|c|}
\hline \multirow[b]{3}{*}{$\begin{array}{l}\text { Bacterial } \\
\text { isolates }\end{array}$} & \multicolumn{8}{|c|}{ Concentration } & \multirow[b]{3}{*}{$\begin{array}{l}\text { Ciprofloxacin } \\
\left(5 \mu \mathrm{gL}^{-1}\right)\end{array}$} \\
\hline & \multicolumn{2}{|l|}{$20 \%$} & \multicolumn{2}{|l|}{$40 \%$} & \multicolumn{2}{|l|}{$80 \%$} & \multicolumn{2}{|l|}{$100 \%$} & \\
\hline & aqaous & ethanol & aqaous & ethanol & aqaous & ethanol & aqueous & ethanol & \\
\hline S. aureus & $9 *$ & 8.6 & 12.0 & 12.5 & 12.4 & 16.3 & 14.5 & 16.0 & 25 \\
\hline S. pyogenes & 8 & 8.1 & 12.1 & 12.5 & 13.0 & 14.8 & 14.6 & 16.3 & 22 \\
\hline E. coli & 0 & 0.0 & 9.3 & 12.0 & 10.2 & 14.8 & 15.2 & 17.0 & 20 \\
\hline Ps. aeruginosa & 0 & 0.0 & 9.5 & 11.0 & 11.3 & 16.0 & 14.9 & 16.6 & 20 \\
\hline
\end{tabular}

* :Mean value of inhibition zone $(\mathrm{mm})$

Table 5 . Antibacterial activity of different concentrations of tumeric against bacterial isolates compared with $\mathrm{Ciprofloxacin}\left(5 \mu \mathrm{g} \mathrm{mL}^{-1}\right)$

\begin{tabular}{|c|c|c|c|c|c|c|c|c|c|}
\hline \multirow[b]{3}{*}{$\begin{array}{l}\text { Bacterial } \\
\text { isolates }\end{array}$} & \multicolumn{8}{|c|}{ Concentration } & \multirow[b]{3}{*}{$\begin{array}{l}\text { Ciprofloxacin } \\
\left(5 \mu \mathrm{g} \mathrm{mL}^{-1}\right)\end{array}$} \\
\hline & \multicolumn{2}{|l|}{$20 \%$} & \multicolumn{2}{|l|}{$40 \%$} & \multicolumn{2}{|l|}{$80 \%$} & \multicolumn{2}{|l|}{$100 \%$} & \\
\hline & aqaous & ethanol & aqaous & ethanol & aqaous & ethanol & aqueous & ethanol & \\
\hline S. aureus & $6.4^{*}$ & 8.0 & 9.5 & 10.5 & 10.1 & 13.0 & 11.6 & 13.5 & 25 \\
\hline S. pyogenes & 7.0 & 9.9 & 10.6 & 13.0 & 11.0 & 13.5 & 12.6 & 14.1 & 22 \\
\hline E. coli & 8.0 & 8.8 & 9.0 & 9.5 & 9.6 & 10.3 & 9.7 & 10.5 & 20 \\
\hline Ps. aeruginosa & 8.3 & 8.5 & 9.0 & 9.3 & 9.5 & 10.1 & 9.7 & 10.4 & 20 \\
\hline
\end{tabular}

\section{Discussion}

Escherichia coli, Staphylococcus aureus, Streptococcus pyogenes and Pseudomonas aeruginosa are the most commonly isolated bacteria from pyogenic skin lesions (Lorrot et al., 2014; Zhang et al., 2014). The tested isolates in the current study were sensitive to ciprofloxacin, which is so far effective against the bacterial infections except in the case of the development of antimicrobial resistance (Sedláková et al., 2014).
Antibiotic resistance poses a growing threat to health. Complementary and Alternative Medicine (CAM) therapies may provide a safer and a more effective treatment (MacKay, 2003). Antimicrobial activities of gold nanoparticles or plant extract differ according to the volume or concentration used and the tested isolates. The antimicrobial ability of gold nanoparticles might be referred to their size which is smaller than the bacterium and fungal cells (Nirmala et al., 2011). This makes them easier to adhere with the cell wall of the microorganisms 
causing its destruction and leading to the death of the cell. Metal nanoparticles are harmful to bacteria and fungi (Chwalibog et al., 2010). Gold nanoparticles stimulate biofilm production and aggregate within a biofilm, they bind closely to the surface of microorganisms causing visible damage to the cells and demonstrating good self-assembling ability. Gold nanoparticles possess well-developed surface chemistry, chemical stability, appropriate smaller size, which make them easier to interact with the microorganisms (Nirmala et al., 2011). The particles interact also with the building elements of the outer membrane and might cause structural changes; degradation and finally cell death. The antibacterial activities of the synthesized gold nanoparticles could be due to the susceptibility of pathogens cell wall and toxicity of metallic gold. Gold nanoparticles exert their antimicrobial action mainly changing the membrane potential and inhibiting ATP syntheses activities to decrease the ATP level, indicating a general decline in metabolism and it also inhibits the ribosome subunit for tRNA binding, indicating a collapse of a biological process. Gold nanoparticles also enhance chemotaxis in the early-phase reaction (Cui et al., 2012). Gold was tested by the well diffusion method against Microsporum gypsum $(10 \mathrm{~mm})$ and Trichophyton rubrum $(13 \mathrm{~mm})$ (Karthik et al., 2013). The accumulation of positively charge gold nanoparticles $(\mathrm{Au}+)$ on the negatively charged cell membrane of microorganisms leads to conformational changes in the membrane, which loses permeability control which in turn cause the cell death (Chwalibog et al., 2010). This may be the possible mechanism of gold nanoparticles which Perform in vitro free radical quenching property; on the other hand, it induces death of the microorganism. However, further studies are required to know more about the biological activity of nanoparticles.

Garlic has shown the best activity and its aqueous extract was more effective as compared to ethanolic extract. Garlic has better activity against $B$. subtilis as compared to $E$. coli and aqueous extract of garlic was more effective as compared to ethanolic extract (Gull et al., 2012). Garlic was more effective against Gram-positive than Gramnegative bacteria (Srinivasans et al., 2009). The Gramnegative E. coli was comparatively resistant to Grampositive bacteria, this may be due to the structure differences in cell membrane and cell wall structure, Gram-negative has outer membrane as well which further block the penetration of antibiotics including the extracts of spices making them resistant. The garlic extract is effective against different serotype of $E$. coli and also S. aureus (Naveed et al., 2013). Fresh garlic concentration $0.5-5.0 \%$ was sufficient to inhibit the growth of E. coli O157: H7 (Tessema et al., 2006).
The ethanolic extract of cinnamon was more efficient than its aqueous extract, as the antimicrobial component of the cinnamon bark is more soluble in ethanol as compared to water, but its activity was reported less as compared to the garlic (Naveed et al., 2013). Cinnamon extract possesses effective antibacterial properties against B. subtilis and E. coli, Gram-positive bacteria are more sensitive to essential oil of Cinnamon zeylanicum than Gram-negative bacteria (Buru et al., 2014). Some molecules of cinnamon oil (cinnamaldehyde and cinnamyl) bind to membrane proteins and inhibit peptidoglycan synthesis, the essential component of the bacterial cell wall, thereby increasing their antibacterial effect (Al-Mariri and Safi, 2014). The antimicrobial activity of cinnamon might be due to the presence of cinnamaldehyde compound which inhibits the amino acid decarboxylation activity in the cell which leads to energy deprivation and microbial cell wall (Ooi et al., 2006). These phenolic compounds are capable of further cellular destruction and inhibition by establishing the hydrophobic and hydrogen bonding of theses degradative phenolic compounds to membrane proteins resulting in portioning of the lipid bilayer (Juven et al., 1994). The antimicrobial activity at aqueous extracts could be due to anionic components such as thiocyanate, nitrate, chlorides and sulfates in addition to many other compounds naturally present in plants (Hill et al., 2014). The ethanolic extracts showed better results as compared to aqueous as being organic dissolves more organic compounds resulting in the release of a greater amount of active antimicrobial components (Cowan, 1999).

Turmeric extract was effective against all tested bacterial isolates in both aqueous and ethanolic solution; Turmeric was effective against E. coli. $b$. subtilus and $s$. aureus due to the presence of a phenolic compound, curcuminoid, the presences of essential oil, an alkaloid, curcumins, turmerol and veleric acid are responsible for the antibacterial activity of turmeric (Moghadamtousi et al., 2014). Chloroform and isoamyl alcohol extracts of Cuminum cyminum showed a significant effect against $P$ s. aeruginosa, S. marcesnces and S. pyogenes (Awan et al., 2013). Aqueous and ethanolic extract of turmeric showed antibacterial activity against all bacterial cells isolated and tested at concentrations of 40, 80 and 100 $\%$, but an aqueous and ethanolic extract of cinnamon has no effect on E. coli and Ps. aeuginosa at $20 \%$ concentration (Fig. 6). Curcumin inhibits bacterial cell division (Rai et al., 2008). Curcumin can be used safely in a wide range of concentrations without toxicity (Yeon et al., 2010). 


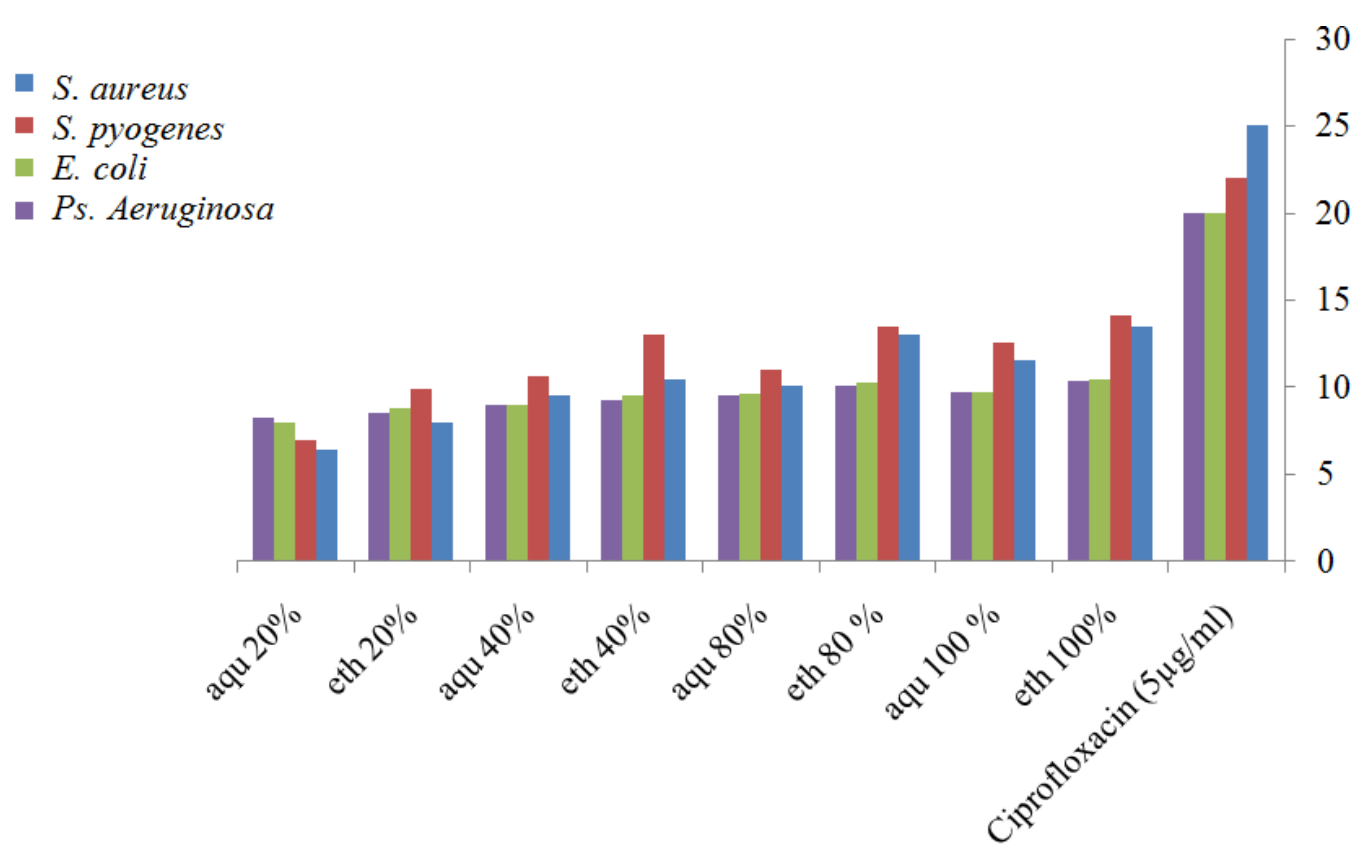

Fig. 6. Antibacterial activity of different concentrations of tumeric against bacterial isolates compared with Ciprofloxacin $\left(5 \mu \mathrm{g} \mathrm{mL} \mathrm{L}^{-1}\right)$

\section{Conclusion}

The present study concluded that gold nanoparticles and plant extract can be used either in aqueous or ethanolic solution to produce new therapeutics. Further research is required for possible future use of these extracts as alternatives to common antibiotics.

\section{Funding Information}

The authors have no support or funding to report.

\section{Author's Contributions}

Iman Shabana: Contributed to the design and the establishment of experiments scheme. Sample collection, isolation and identification of the bacterial isolates. The performance of the disc diffusion assay. Data modeling, analysis and interpretation. The orientation of statistical graphics. Contributed to the writing of the manuscript. Important review contributions.

Amira El-Adly: Contributed to the design and the establishment of experiments scheme. Preparation of extracts and gold nanoparticles. The performance of the disc diffusion assay. Data modeling, analysis and interpretation. Contributed to the writing of the manuscript. Important review contributions.

\section{Ethics}

This article is original and contains unpublished material. The corresponding author confirms that all of the other authors have read and approved the manuscript and no ethical issues involved.

\section{References}

Al-Mariri, A. and M. Safi, 2014. In vitro antibacterial activity of several plant extracts and oils against some gram-negative bacteria. Iran J. Med. Sci., 39: 36-43. PMID: 24453392

Al-Talib, H., C.Y. Yean, A. Al-Khateeb, H. Hassan and K.K. Singh et al., 2009. A pentaplex PCR assay for the rapid detection of methicillin-resistant Staphylococcus aureus and Panton-Valentine Leucocidin. BMC Microbiol., 9: 113-113. DOI: $10.1186 / 1471-2180-9-113$

Aly, S.M., 2013. Risk of antimicrobial misuse. Int. J. Health Sci., 7: 5-7. DOI: 10.12816/0006014

AFHSC, 2013. Bacterial skin infections, active component, U.S. Armed Forces, 2000-2012. MSMR., 20: 2-7. PMID: 24428536

Awan, U.A., S. Andleeb, A. Kiyani, A. Zafar and I. Shafique et al., 2013. Antibacterial screening of traditional herbal plants and standard antibiotics against some human bacterial pathogens. Pak. J. Pharm. Sci., 26: 1109-1116. PMID: 24191314

Bajpai, M., A. Pande, S.K. Tewari and D. Prakash, 2005. Phenolic contents and antioxidant activity of some food and medicinal plants. Int. J. Food Sci. Nutr., 56: 287-291. DOI: 10.1080/09637480500146606

Buru, A.S., M.R. Pichika, V. Neela and K. Mohandas, 2014. In vitro antibacterial effects of Cinnamomum extracts on common bacteria found in wound infections with emphasis on methicillin-resistant Staphylococcus aureus. J. Ethnopharmacol., 153: 587-595. DOI: 10.1016/j.jep.2014.02.044 
Cheesbrough, M., 2000. District Laboratory Practice in Tropical Countries, Part 2. 2nd Edn., Cambridge University Press, Cambridge,

ISBN-10: 0521676312, pp: 440.

Chwalibog, A., E. Sawosz, A. Hotowy, J. Szeliga and S. Mitura et al., 2010. Visualization of interaction between inorganic nanoparticles and bacteria or fungi. Int. J. Nanomed., 5: 1085-1094. DOI: $10.2147 /$ IJN.S13532

Clifford, R.J., M. Milillo, J. Prestwood, R. Quintero and D.V. Zurawski et al., 2012. Detection of bacterial $16 \mathrm{~S}$ rRNA and identification of four clinically important bacteria by real-time PCR. PLoS One., 7: e48558-e48558. PMID: 23139793

Cowan, M.M., 1999. Plant products as antimicrobial agents. J. Clin Microbiol. Rev., 12: 564-582. PMID: 10515903

Cui, Y., Y. Zhao, Y. Tian, W. Zhang and X. Lux, 2012. The molecular mechanism of action of bactericidal gold nanoparticles on Escherichia coli. Biomaterials., 33: 2327-2333.

DOI: $10.1016 /$ j.biomaterials.2011.11.057

Eby, D.M., N.M. Shaeublin, K.E. Farrington, S.M. Hussain and G.R. Johnson, 2009. Lysozyme catalyzes the formation of antimicrobial silver nanoparticles. ACS. Nano., 3: 384-394. DOI: $10.1021 / \mathrm{nn} 900079 \mathrm{e}$

Farzaei, M.H., R. Rahimi, F. Attar, F. Siavoshi and P. Saniee et al., 2014. Chemical composition, antioxidant and antimicrobial activity of essential oil and extracts of Tragopogon graminifolius, a medicinal herb from Iran. Nat. Prod. Commun., 9: 121-124. PMID: 24660479

Gull, I., M. Saeed, H. Shaukat, S.M. Aslam and Z.Q. Samra et al., 2012. Inhibitory effect of Allium sativum and Zingiber officinale extracts on clinically important drug resistant pathogenic bacteria. Ann. Clin. Microbiol. Antimicrob., 27: 11-18.

DOI: $10.1186 / 1476-0711-11-8$

Hill, E.H., H.C. Pappas and D.G. Whitten, 2014. Activating the antimicrobial activity of an anionic singlet-oxygen sensitizer through surfactant complexation. Langmuir, 30: 5052-5056. DOI: $10.1021 / \mathrm{la} 501230 \mathrm{~m}$

Izui, S., S. Sekine, K. Maeda, M. Kuboniwa and A. Takada et al., 2015. Antibacterial activity of curcumin against periodontopathic bacteria. J. Periodontol., 8: 1-18. PMID: 26447754

Juven, B.J., J. Kanner, F. Sched and H. Weissslowic, 1994. Factors that interact with the antibacterial action of thyme essential oil and its active constituents. J. Applied Microbiol., 76: 626-631. PMID: 8027009

Karthik, L., G. Kumar, T. Keswani, A. Bhattacharyya and B.P. Reddy et al., 2013. Marine actinobacterial mediated gold nanoparticles synthesis and their antimalarial activity. Nanomedicine., 9: 951-960. PMID: 23434675
Kaushik, D., J. Yadav, P. Kaushik, D. Sacher and R. Rani, 2011. Current pharmacological and phytochemical studies of the plant Alpinia galanga. J. Chin. Integr. Med., 9: 1061-1065.

DOI: $10.3736 /$ jcim 20111004

Koneman, W.K., S.D. Allen, W.M. Janda, P.C. Schreckenberger and G.W. Procop et al., 2005. Jr. Philadelphia color atlas and textbook of diagnostic microbiology. Lippincott-Raven Publisher.

Koutinas, A.F., M.N. Saridomichelakis, S. Argyroudis, C.K. Koutinas and P. Karatzanos et al., 2007. Clinical, histopathological and therapeutic considerations in a flock of sheep with facial staphylococcal-associated dermatitis. Vet. Dermatol., 18: 211-6.

Li, W.R., X.B. Xie, Q.S. Shi, H.Y. Zeng and Y.S. Ou-Yang et al., 2010. Antibacterial activity and mechanism of silver nanoparticles on Escherichia coli. Applied Microbiol. Biotechnol., 85: 1115-1122. DOI: 10.1007/s00253-009-2159-5

Lorrot, M., E. Bourrat, C. Doit, S. Prot-Labarthe and S. Dauger et al., 2014. Superficial skin infections and bacterial dermohypodermitis. Arch Pediatr., 14: 162-166. PMID: 24957981

MacKay, D., 2003. Can CAM therapies help reduce antibiotic resistance? Altern Med. Rev., 8: 28-42. PMID: 12611559

Moghadamtousi, S.Z., H.A. Kadir, P. Hassandarvish, H. Tajik and S. Abubakar et al., 2014. A review on antibacterial, antiviral and antifungal activity of curcumin. Biomed. Res. Int. DOI: $10.1155 / 2014 / 186864$

Moyo, S.J., S.Y. Maselle, M.I. Matee, N. Langeland and H. Mylvaganam, 2007. Identification of diarrheagenic Escherichia coli isolated from infants and children in Dar es Salaam, Tanzania. BMC Infect. Dis., 9: 7-92. PMID: 17688682

Nabavi, S.F., A. Di Lorenzo, M. Izadi, E. Sobarzo-S Unchez and M. Daglia et al., 2015. Antibacterial effects of cinnamon: From farm to food, cosmetic and pharmaceutical industries. Nutrients, 7: 7729-7748. PMID: 26378575

Naveed, R.1., I. Hussain, A. Tawab, M. Tariq and M. Rahman, 2013. Antimicrobial activity of the bioactive components of essential oils from Pakistani spices against Salmonella and other multidrug resistant bacteria. BMC Complement Altern Med., 14: 265-265. PMID: 24119438

Nirmala, R., H.M. Park, D. Kalpana, H.S. Kang and R. Navamathavan et al., 2011. Bactericidal activity and in vitro cytotoxicity assessment of hydroxyapatite containing gold nanoparticles. J. Biomed. Nanotechnol., 7: 342-350.

DOI: $10.1166 /$ jbn.2011.1292 
Ooi, L.S., Y. Li, S.L. Kam, H. Wang and E.Y. Wong et al., 2006. Antimicrobial activities of cinnamon oil and cinnamaldehyde from the Chinese medicinal herb Cinnamomum cassia Blume. Am. J. Chin. Med., 34: 511-522. DOI: 10.1142/S0192415X06004041

Panacek, A., M. Kolar, R. Vecerova, R. Prucek and J. Soukupov J et al., 2009. Antifungal activity of silver nanoparticles against Candida spp. Biomaterials, 31: 6333-6340.

DOI: $10.1016 /$ j.biomaterials.2009.07.065

Rai, D., J.K. Singh, N. Roy and D. Panda, 2008. Curcumin inhibits fast assembly: An attractive mechanism for it antibacterial activity. Biochem. J., 410: 147-155. DOI: 10.1042/BJ20070891

Samie, A., C.L. Obi, N. Lall and J.J. Meyer, 2009. Invitro cytotoxicity and antimicrobial activities, against clinical isolates of Campylobacter species and Entamoeba histolytica, of local medicinal plants from the Venda region, in South Africa. Ann. Trop. Med. Parasitol., 103: 159-170.

DOI: $10.1179 / 136485909 X 384992$

Sedláková, M.H., K. Urbánek, V. Vojtová, H. Suchánková and P. Imwensi et al., 2014. Antibiotic consumption and its influence on the resistance in Enterobacteriaceae. BMC Res Notes., 7: 454.

Shaheen, A.Y., A.A. Sheikh, M. Rabbani, A. Aslam and T. Bibi et al., 2015. Antibacterial activity of herbal extracts against multi-drug resistant Escherichia coli recovered from retail chicken meat. Pak. J. Pharm. Sci., 28: 1295-1300. PMID: 26142503

Srinivasans, D., S. Nathan, T. Suresh and P.L. Perumalsamy, 2009. Antimicrobial activity of certain Indian medicinal plants used in folkloric medicine. J. Ethnopharm., 74: 217-220.

DOI: $10.1016 / \mathrm{S} 0378-8741(00) 00345-7$
Tessema, B., A. Mulu, A. Kassu and G. Yismaw, 2006. An in vitro assessment of the antibacterial effect of garlic (Allium sativum) on bacterial isolates from wound infections. Ethiop Med. J., 44: 385-389. PMID: 17370439

Usein, C.R., D. Tatu-Chitoiu, S. Ciontea, M. Condei and M. Damian, 2009. Escherichia coli pathotypes associated with diarrhea in Romanian children younger than 5 years of age. Jpn. J. Infect. Dis., 62: 289-293. PMID: 19628907

Violante, I.M., L. Hamerski, W.S. Garcez, A.L. Batista and M.R. Chang et al., 2012. Antimicrobial activity of some medicinal plants from the cerrado of the central-western region of Brazil. Braz. J. Microbiol., 43: 1302-1308. DOI: $10.1590 / \mathrm{S} 1517-83822012000400009$

Wikler, M.A., 2006. Performance Standards for Antimicrobial Disk Susceptibility Tests: Approved Standard. 9th Edn., Clinical and Laboratory Standards Institute, Wayne, PA., ISBN-10: 1562385860, pp: 37.

Yang, Y., M. Nogami, J. Shi, H. Chen and G. Ma et al., 2005. Enhancement of third-order optical nonlinearities in 3-dimensional films of dielectric shell capped $\mathrm{Au}$ composite nanoparticles. J. Phys. Chem. B., 109: 4865-4871. DOI: 10.1021/jp045854a

Yeon, K.Y., S.A. Kim, Y.H. Kim, M.K. Lee and D.K. Ahn et al., 2010. Curcumin produces an antihyperalgesic effect via antagonism of TRPV1. J. Dent. Res., 89: 170-174. DOI: $10.1177 / 0022034509356169$

Zhang, S., L. Ren, Y. Li, J. Wang and W. Yu et al., 2014. Bacteriology and drug susceptibility analysis of pus from patients with severe intra-abdominal infection induced by abdominal trauma. Exp. Ther. Med., 7: 1427-1431. DOI: 10.3892/etm.2014.1609 